7. Zachary KC, Bayne PS, Morrison VJ, Ford DS, Silver LC, Hooper DC. Contamination of gowns, gloves, and stethoscopes with vancomycin-resistant enterococci. Infect Control Hosp Epidemiol 2001;22:560-564.

8. Schaffzin JK, Southwick KL, Clement EJ, et al. Transmission of hepatitis B virus associated with assisted monitoring of blood glucose at an assisted living facility in New York State. Am J Infect Control 2012;40:726-731.

9. Centers for Disease Control and Prevention (CDC). Guideline for Disinfection and Sterilization in Healthcare Facilities, 2008. Atlanta: CDC, 2008. http://www.cdc.gov/hicpac/pdf/guidelines /Disinfection_Nov_2008.pdf. Accessed June 20, 2013.

\section{Sharing Eyedrops between Patients: When Will It End?}

To the Editor-The Centers for Disease Control and Prevention recently released a Morbidity and Mortality Weekly Report on 6 outbreaks of adenovirus-associated keratoconjunctivitis in 4 US states occurring between 2008 and $2010{ }^{1}$ These epidemics occurred in outpatient ophthalmologic clinics and a neonatal intensive care unit, and a total of 411 cases were identified. A goal of the American Academy of Ophthalmology Infection Prevention Statement (2012) is zero tolerance for healthcare-associated infections. The academy acknowledges that adenovirus is the main cause of nosocomial outbreaks of conjunctivitis occurring in eye clinics, nursing homes, and child care centers and that transmission can occur from ophthalmic solutions and instruments. The academy condones the practice of sharing eyedrop containers between patients on the condition that they are discarded if the patient has an obvious eye infection or the container tip has direct contact with the patient's tears or conjunctiva. ${ }^{2}$ However, it may not always be apparent to the healthcare worker that a patient has an infectious eye disease. Adenovirus can be transmitted a few days before symptoms develop and can be shed long after symptoms have resolved. Some patients are asymptomatic, and others may have mild symptoms. ${ }^{1-3}$ Clearly, if there is any physical contact between the eyedrop bottle and the conjunctiva, eyelashes, or tears, there is the potential to transmit disease to other patients.

Prior studies have shown that adenovirus is a virulently growing organism that can survive in the eyedrops of patients with confirmed adenovirus for up to 9 weeks after contamination. ${ }^{4,5}$ In several studies, many organisms have been grown from ophthalmology solutions that were used on multiple patients in a variety of settings, including a primary care setting, ophthalmology clinics, and long-term care facilities. These include normal skin contaminants, such as coagulasenegative Staphylococcus, Propionbacterium acnes, and Streptococcus viridans, as well as pathogens such as Pseudomonas putida, Burkholderia cepacia, and Serratia marcescans. ${ }^{6,7}$

Currently, most healthcare facilities consider larger-volume eyedrop medications for multipatient use to be more economically viable than single-patient-use eyedrop vials. However, this ignores the cost of outbreaks of nosocomial infections related to the use of multipatient eyedrop bottles. As we strive to reduce all healthcare-associated infections, we should encourage the manufacture of inexpensive singlepatient eyedrops for use in healthcare facilities. While there is any opportunity for the transmission of bacteria or viruses to occur, it is surprising that the sharing of any kind of medication between patients in healthcare settings is still considered acceptable practice.

\section{ACKNOWLEDGMENTS}

Potential conflicts of interest. All authors report no conflicts of interest relevant to this article. All authors submitted the ICMJE Form for Disclosure of Potential Conflicts of Interest, and the conflicts that the editors consider relevant to this article are disclosed here.

Joanne Kinlay, RN, BSN, MMedSci(ClinEpi), CIC ${ }^{1}$

Affiliation: 1. Infection Prevention and Control, Boston Children's Hospital, Boston, Massachusetts.

Address correspondence to Joanne Kinlay, RN, BSN, MMedSci(ClinEpi), CIC, Infection Prevention and Control, Boston Children's Hospital, 300 Longwood Avenue, Boston, MA 02115 (joanne.kinlay@childrens.harvard.edu). Infect Control Hosp Epidemiol 2013;34(12):1333-1333

(C) 2013 by The Society for Healthcare Epidemiology of America. All rights reserved. 0899-823X/2013/3412-0021\$15.00. DOI: $10.1086 / 673993$

\section{REFERENCES}

1. King D, Johnson B, Miller D, et al. Adenovirus-associated epidemic keratoconjunctivitis outbreaks-four states, 2008-2010. MMWR Morb Mortal Wkly Rep 2013;62(32);637-641.

2. American Academy of Ophthalmology. Infection Prevention in Eye Care Services and Operating Areas. http://one.aao.org/clinical -statement/infection-prevention-in-eye-care-services-operatin. Published August 2012. Accessed October 24, 2013.

3. Bhumbra N, Wroblewski M. Adenovirus. Pediatr Rev 2010;31: 173-174.

4. Uchio E, Ishiko H, Aoki K, Ohno S. Adenovirus detected by polymerase chain reaction in multidose eyedrop bottles used by patients with adenoviral keratoconjunctivitis. Am J Ophthalmol 2002;134(4):618-619.

5. Viney K, Kehoe P, Doyle B, et al. An outbreak of epidemic keratoconjunctivitis in a regional ophthalmology clinic in New South Wales. Epidemiol Infect 2008;136:1197-1206.

6. Clark PJ, Ong B, Stanley C. Contamination of diagnostic ophthalmic solutions in primary eye care settings. Mil Med 1997;162: 501-506.

7. Geyer O, Bottone E, Podos S, Schumer R, Asbell P. Microbial contamination of medications used to treat glaucoma. $\mathrm{Br} J$ Ophthalmol 1995;79(4):376-379. 